\title{
REVIEW
}

\section{Vitamin D Deficiency and Pain: Clinical Evidence of Low Levels of Vitamin D and Supplementation in Chronic Pain States}

\author{
Elspeth E. Shipton · Edward A. Shipton
}

To view enhanced content go to www.paintherapy-open.com Received: February 1, 2015 / Published online: April 29, 2015

(C) The Author(s) 2015. This article is published with open access at Springerlink.com

\begin{abstract}
Introduction: A number of studies suggest a link between low levels of 25-hydroxy vitamin $\mathrm{D}$ and incidence of acute and chronic pain. Clinical studies of vitamin D supplementation in patients with known vitamin D deficiency have shown mixed results in improving pain scores.
\end{abstract}

Methods: In this article, vitamin D deficiency risk factors are observed and adequate levels of 25-hydroxy vitamin D defined. Clinical supplementation with vitamin D is explored, including the schedules used in published clinical trials. Evidence of the effectiveness of vitamin D supplementation for the treatment of chronic pain conditions from double-blind randomized controlled trials (RCTs) is examined.

Results: The scientific evidence for vitamin D as a treatment option for chronic pain is limited

Electronic supplementary material The online version of this article (doi:10.1007/s40122-015-0036-8) contains supplementary material, which is available to authorized users.

E. E. Shipton · E. A. Shipton ( $\square)$

Department of Anaesthesia, University of Otago,

Christchurch, New Zealand

e-mail: shiptonea@xtra.co.nz due to lack of RCTs. It cannot be stated conclusively that vitamin $\mathrm{D}$ deficiency is directly linked to the etiology or maintenance of chronic pain states.

Conclusion: There remains a growing body of both clinical and laboratory evidence pointing to a potential relationship between low levels of 25-hydroxy vitamin $\mathrm{D}$ and a variety of chronic pain states. More focused research involving large RCTs is necessary.

Keywords: Chronic Pain; Pain Processes; Supplementation; Vitamin D deficiency

\section{INTRODUCTION}

It appears that circulating vitamin $\mathrm{D}$, the parent compound for tissue vitamin $\mathrm{D}$ activation, has an important direct physiological role beyond what was originally anticipated through the local tissue autocrine system [1]. A number of studies have suggested a link between low levels of 25-hydroxy vitamin $\mathrm{D}[25(\mathrm{OH}) \mathrm{D}]$ and the incidence of both acute and chronic pain [2-5]. Clinical studies of vitamin D supplementation in patients with known vitamin D deficiency have shown mixed results in improving pain 
scores [6]. Vitamin D is cheap and has relatively few adverse effects. Its use in chronic pain could therefore be advocated even if the benefit was of modest size [4]. In general, there is a positive public perception of vitamin supplementation which could result in high rates of adherence [4].

\section{Synthesis, Absorption, and Metabolism of Vitamin D}

Chemically, vitamin $\mathrm{D}$ is a fat-soluble secosteroid (that is, a steroid in which one of the bonds in the steroid rings is broken). The most common forms are vitamin $\mathrm{D}_{3}$ (cholecalciferol) and vitamin $\mathrm{D}_{2}$ (ergocalciferol), which are collectively known as calciferol. Although it is called a vitamin, vitamin $\mathrm{D}$ is really a hormone. It can be produced endogenously by humans in the skin from a precursor 7-dehydrocholesterol which is converted to vitamin $\mathrm{D}_{3}$ after exposure to ultraviolet B. Vitamin D can also be obtained from a limited number of dietary sources; vitamin $D_{2}$ from plant origins and vitamin $D_{3}$ from animal origins. However, few foods have naturally occurring substantial vitamin $\mathrm{D}_{2}$ and vitamin $\mathrm{D}_{3}$ levels to make this a significant source of vitamin D in humans.

Vitamin D from the skin and diet is hydroxylated in the liver by one of several cytochrome P450 enzymes to the prehormone 25-hydroxy vitamin D [calcidiol, or 25(OH)D] that is encoded by the gene CYP27A1 [7-9]. Most circulating 25(OH)D and the active form of vitamin $\mathrm{D}$, namely 1,25-dihydroxy-vitamin $\mathrm{D}$ $\left[1,25(\mathrm{OH})_{2} \mathrm{D}_{3}\right]$, are transported in the blood bound to vitamin D-binding protein (DBP; 80-90\%) and to albumin (10-20\%); only a small fraction remains free or unbound [10].

However, vitamin D can also be hydroxylated to $25(\mathrm{OH}) \mathrm{D}$ in all tissues of the body, achieving autocrine production of $25(\mathrm{OH}) \mathrm{D}$ in these tissues [1]. 25(OH)D is then further metabolized in the kidneys and possibly in a wide variety of extra-renal tissues by the enzyme 25-hydroxyvitamin D-1 $\alpha$-hydroxylase (CYP27B1) to its active form, namely, 1,25dihydroxy-vitamin $\mathrm{D}\left[1,25(\mathrm{OH})_{2} \mathrm{D}_{3}\right]$. Vitamin D exerts its effects by modulating gene expression after binding to vitamin D receptor (VDR). There appear to be potential genetic polymorphisms in key genes with vitamin D exposure that can influence bioavailability, transport, and distribution in lipid storage pools, metabolism, and action of vitamin D [8].

\section{Chronic Pain}

The International Association for the Study of Pain (IASP) defines chronic pain as "pain that has persisted beyond normal tissue healing time". This is taken (in absence of other criteria) to be 3 months [11]. However, some chronic pain disorders are characterized by recurrent short acute episodes and exacerbations such as trigeminal neuralgia and rheumatoid arthritis.

Chronic pain can be produced after tissue damage (or inflammation), nerve damage, and after alteration of normal neural function. Chronic persistent pain leads to chemical, functional, and anatomical changes throughout the nervous system (in the periphery, spinal cord, and brain) [12-14]. In chronic pain states, the nervous system is altered to produce spontaneous pain that arises without any apparent peripheral stimulus as well as a hypersensitivity to peripheral stimuli [15-18]. Pain hypersensitivity potentiates hyperalgesia (the exaggerated and prolonged response to noxious stimulation) and allodynia (pain resulting from a stimulus that is normally nonpainful) [19]. Reduced descending inhibition in 
the central nervous system results in increased peripheral noxious signals that provide messages to the brain, and result in an increased experience of pain [20].

\section{THE INTERFACE OF VITAMIN D AND CHRONIC PAIN}

Research has shown that vitamin D exerts anatomic, hormonal, neurological, and immunological influences on pain manifestation, thereby potentially playing a role in the etiology and maintenance of chronic pain states and associated comorbidities [21-24]. $1,25(\mathrm{OH})_{2} \mathrm{D}_{3} \quad$ (i.e., calcitriol) is an active vitamin $\mathrm{D}$ metabolite. It plays a role in many biological processes, especially in bone metabolism and muscle function, and is mediated by VDRs [25]. Vitamin D supplementation has been found to improve bone density and musculoskeletal symptoms [26]. Vitamin D deficiency causes muscle weakness and pain in children and adults [27, 28]. Low bone density and osteopenia appear to contribute to chronic pain in patients with cystic fibrosis, and are related to low $25(\mathrm{OH}) \mathrm{D}$ levels $[29,30]$.

Low $25(\mathrm{OH}) \mathrm{D}$ levels have been found to be related to heightened central sensitivity (particularly augmented pain processing) upon mechanical stimulation in chronic pain patients [31]. Migraine and fibromyalgia represent a central neural hypersensitivity [32, 33]. Activated microglia, astrocytes, and spinal glia release a variety of neuroexcitatory substances (nitric oxide, excitatory amino acids, proinflammatory cytokines, and mediators) that potentially initiate and maintain the neural hypersensitivity state seen in chronic pain states [32]. As a neuroactive steroid, vitamin $\mathrm{D}$ can modulate neuronal excitability including spontaneous regular firing, action potential duration, intrinsic excitability and sensitivity to neurotransmitters (gonadotropinreleasing hormone, opioidergic neurons) as well as to neurotransmitter receptors such as gammaaminobutyric acid and $\mathrm{N}$-methyl-D-aspartate [34-36]. Vitamin D plays a fundamental role in astrocyte detoxification pathways, and thereby exerts a neuroprotective effect [37]. Vitamin D suppresses tumor necrosis factor alpha (TNF $\alpha)$, macrophage colony-stimulating factor (M-CSF), and inducible nitric oxide synthase in astrocytes and microglia [38]. TNF $\alpha$ has been convincingly implicated at both peripheral and central levels of sensitization [39]. M-CSF is a cytokine that stimulates proliferation, differentiation, and survival of monocytes and macrophages. Macrophages can release many inflammatory mediators, including proinflammatory cytokines, particularly TNF $\alpha$ and interleukin-1 beta (IL-1 $\beta$ ), nerve growth factor (NGF), nitric oxide (NO), and the prostanoids [40]. By limiting M-CSF, vitamin D has the potential to inhibit pain pathways. The presence of VDR, $1 \alpha$ hydroxylase, and DBP in the hypothalamus is suggested as the mechanism by which vitamin $\mathrm{D}$ deficiency is implicated in the pathophysiology of various primary headache disorders [41]. Vitamin D upregulates the synthesis of neurotrophins such as NGF, neurotrophin 3, and glial cell line-derived neurotrophic factor, whereas neurotrophin 4 is down-regulated [37, $38,42-44]$. Through this system, vitamin D can potentially affect the development of neurons, as well as their maintenance and survival. NGF is a well-established inflammatory mediator and has direct effects on the sensory nerve endings causing hypersensitivity, amplification of sensory input signals, and enhanced innervation of injured tissue [40, 45-47].

Individuals with sickle cell disease may develop chronic pain for a variety of reasons 
including vascular occlusive bone infarction, peripheral nerve injury, central pain sensitization, as well as hyperalgesia syndrome from prolonged high-dose opioid use [48].

\section{VITAMIN D DEFICIENCY}

\section{General Prevalence of and Risk Factors Associated With Vitamin D Deficiency}

There appears to be a worldwide trend towards nutritional vitamin D deficiency that is causing concern [9]. Estimates of vitamin D deficiency vary across the world and within countries themselves. It has been estimated that a wide range $(20-100 \%)$ of elderly men and women living in the community in the United States, Canada, and Europe are vitamin D deficient [49].

The major cause of vitamin D deficiency is decreased sun exposure that limits the synthesis of vitamin D [49]. This could occur through stringent application of sunscreen, or active avoidance of the sun for presumed health reasons [50]. Women who cover themselves for cultural or religious reasons are at risk of vitamin $\mathrm{D}$ deficiency as well [51]. People with naturally dark skin tone appear to require at least three to five times longer sun exposure to make the same amount of vitamin $\mathrm{D}$ as a person with a white skin tone [49]. People with dark-colored skin who live far from the equator are at high risk of developing a vitamin D deficiency. However, there is also evidence that dark-skinned people can be at risk even in sunny climate such as Australia [50]. Age, gender, and race can be factors associated with risk of vitamin D deficiency. In the United States, serum levels of 25(OH)D (nmol/L) among 15,390 adult participants more than or equal to 18 years of age were evaluated [52]. White men and women (83.0 and $76.0 \mathrm{nmol} / \mathrm{L}$, respectively) had higher mean serum levels of $25(\mathrm{OH}) \mathrm{D}$ than Hispanic men and women $(68.3 \mathrm{nmol} / \mathrm{L}$ and $56.7 \mathrm{nmol} / \mathrm{L}$, respectively; $P<0.0001)$, and had higher mean serum levels of $25(\mathrm{OH}) \mathrm{D}$ than black men and women $(52.2$ and $45.3 \mathrm{nmol} / \mathrm{L}$, respectively; $P<0.0001)$ as well. The prevalence of both mild to moderate and severe deficiency of $25(\mathrm{OH}) \mathrm{D}$ was higher among women $(P<0.0001)$ and in minority populations $(P<0.0001)$. However, even amongst white men, $34 \%$ were found to have low 25(OH)D levels [52].

The elderly are particularly at risk as the body's ability to synthesize vitamin $\mathrm{D}$ in the skin decreases with aging [21]. Being less mobile and often confined indoors, their exposure to sunlight can be limited. This applies particularly to institutionalized individuals [50, 53]. Despite the sunny climate in Australia, in a large sample of women in residential care in three of the states, mean 25(OH)D serum levels fell below 50, and below $31.4 \mathrm{nmol} / \mathrm{L}$ if they were in high-level care [54]. Neonates may be deficient due to low serum maternal 25(OH)D levels caused by multiparity and by dark maternal skin with restricted sun exposure [50]. Exclusively breast-fed infants, particularly if dark skinned with little exposure to sunlight, are at risk as well [55].

Patients with malabsorption syndromes such as cystic fibrosis, cholestatic liver disease, chronic inflammatory bowel disease (Crohn's disease), or a short bowel syndrome are at risk of developing vitamin D deficiency through limited absorption of dietary vitamin D [50, 56]. Vegetarians may also be at risk of dietary vitamin D deficiency [50]. Obesity is associated with vitamin $\mathrm{D}$ deficiency in both adults and children [57-60]. This could be related to increased storage of vitamin $\mathrm{D}$ in adipose tissue, limited sun exposure due to increased clothing and immobility, or due to the fact that low vitamin D levels cause parathyroid hormone (PTH) excess and calcium influx into 
adipocytes, promoting weight gain [61]. However, it is not known whether adipose tissue merely sequesters vitamin $\mathrm{D}$ and its metabolites or whether it functions as a storage pool from which vitamin $\mathrm{D}$ and its metabolites can be mobilized [8].

People taking anticonvulsants, glucocorticoids, rifampicin, or highly active antiretroviral drugs are at higher risk of developing vitamin $\mathrm{D}$ insufficiency $[49,50]$. These drugs enhance the catabolism of $25(\mathrm{OH}) \mathrm{D}$ and of $1,25(\mathrm{OH})_{2} \mathrm{D}_{3}[49$, 50].

\section{Defining Adequate of Vitamin D Levels}

At present, assessment of serum 25(OH)D provides the best measure of vitamin $\mathrm{D}$ repletion in humans, reflecting exposure to dietary or endogenous sources of vitamin D as well as indicating other processes such as absorption and metabolism $[8,10,62]$. One functional definition of the optimal vitamin $\mathrm{D}$ status is the 25(OH)D levels that maximally suppress PTH [63, 64]; the reason for this is that the major stimulus for PTH secretion is a low level of serum calcium $[7,65]$. It is generally agreed that the levels of PTH will start to rise significantly once the serum 25(OH)D levels drops below $75 \mathrm{nmol} / \mathrm{L}$ [50]. Many vitamin D scientists advise that the minimum serum 25(OH)D levels should be $75 \mathrm{nmol} / \mathrm{L}[9,49,66]$. Most experts now define frank vitamin D deficiency as a serum $25(\mathrm{OH}) \mathrm{D}$ level of less than $50 \mathrm{nmol} / \mathrm{L}[49,50,65,67]$. Serum levels between 50 and $75 \mathrm{nmol} / \mathrm{L}$ are considered to represent vitamin D insufficiency [9].

\section{Clinical Supplementation with Vitamin D}

Vitamin D supplementation increases $25(\mathrm{OH}) \mathrm{D}$ serum levels and can therefore potentially correct the effects of vitamin D deficiency [4]. The impact of dietary intake on vitamin D metabolism and the reversibility of chronic pain with normalization of serum 25(OH)D levels remain unclear at present. Variation in vitamin D dosing schedules could have a profound effect in the outcome of clinical trials because of the short circulating half-life of intact vitamin D [1]. The cellular accessibility of the parent compound vitamin $\mathrm{D}$, as well as that of $25(\mathrm{OH}) \mathrm{D}$, is important when considering supplementing with vitamin $\mathrm{D}$ in a clinical trial. 25(OH)D and vitamin $\mathrm{D}$ can be internalized by cells through one of two mechanisms. Free $25(\mathrm{OH}) \mathrm{D}$ can enter the cell by diffusion across the cell membrane or by the DBP receptor-mediated endocytosis by the coreceptors megalin and cubilin [8]. Most circulating vitamin $\mathrm{D}$ and $25(\mathrm{OH}) \mathrm{D}$ are transported in the blood bound to DBP. The $25(\mathrm{OH}) \mathrm{D}$ is tightly bound to DPB. The amount of DBP and its effect on free versus bound $25(\mathrm{OH}) \mathrm{D}$ could inversely affect the free $25(\mathrm{OH}) \mathrm{D}$ available for uptake by diffusion into cells [8]. This simple diffusion is primarily controlled by the dissociation constant of the vitamin D compound to the DBP. The amount of DBP could also directly influence the uptake of $25(\mathrm{OH}) \mathrm{D}$ via the megalin and cubilin coreceptor system [1].

Selection of dosing regimen, such as whether to give supplements at daily, weekly, monthly, or longer intervals, is important in clinical trials of vitamin $\mathrm{D}$ as different regimes could influence the outcomes of such studies. Longterm daily dosing of vitamin $\mathrm{D}$ will result in a slow rise in circulating serum $25(\mathrm{OH}) \mathrm{D}$ levels that will reach a steady state at 3-6 months [1]. Stable circulating serum levels of both vitamin $\mathrm{D}$ and $25(\mathrm{OH}) \mathrm{D}$ result from daily dosing schedules, whereas weekly doses result in varying serum levels of circulating vitamin $\mathrm{D}$ but stable serum levels of 25(OH)D [68-70]. Acute or large bolus dosing with vitamin D 
Table 1 Dosing schedules of vitamin D $[68,71-78]$

\begin{tabular}{ll}
\hline Dose schedule & Dose range (IU) \\
\hline Daily & $400-4000$ \\
Weekly & $8400-50,000$ \\
Monthly & $50,000-120,000$ \\
Four-monthly & $100,000^{\mathrm{a}}$ \\
Yearly & $300,000-600,000$ \\
\hline
\end{tabular}

${ }^{a}$ Four-monthly dosing schedule was only mentioned in one research trial

appears to produce a variety of rates of $25(\mathrm{OH}) \mathrm{D}$ [1].

A wide variety of schedules have been used in published clinical trials (Table 1 [71-78] ). However, clinical research studies have shown that supplementary doses less than 1000 IU per day of vitamin $\mathrm{D}$ results in only modest increases in serum levels of $25(\mathrm{OH}) \mathrm{D}$ that may be inconsequential for achieving optimal serum levels of $75 \mathrm{nmol} / \mathrm{L}[79,80]$.

There does not appear to be any variation in tolerance or toxicity of vitamin $\mathrm{D}$ in terms of the dosing regimen [1]. It has been suggested that optimal benefits from vitamin D supplementation would be achieved through a daily dose of vitamin $D$ to ensure stable circulating serum levels over time [1]. Oncedaily dosing appeared to be more effective than monthly or 3-monthly dosing in prevention of respiratory tract infections [81]. However, poor adherence with daily dosing of medications and supplements is widely appreciated [72]. Thus, higher and longer interval dosing is likely to result in better adherence. Weekly dosing would be preferable over monthly due to the 3-4 week half-life of $25(\mathrm{OH}) \mathrm{D}$ [72]. In a recent study of patients supplemented with either $1200 \mathrm{IU}$ daily or 50,000 IU weekly of vitamin D for 3 months, the serum 25(OH)D level improved in both groups by almost $40 \%$, but the difference in improvement was not statistically significant between the subgroups [82]. Fourmonthly vitamin D supplementation has also been shown to result in positive functional outcomes [78].

Studies have shown that time to equilibrium for vitamin D supplementation is generally 3 to 6 months [83-87].

Vitamin D has relatively few (and usually mild) adverse effects. Excessive inputs of vitamin D potentially produce hypercalcemia, renal stones, and renal calcification, with kidney failure and death. Extremely high serum levels of either $25(\mathrm{OH}) \mathrm{D}$ or of vitamin $\mathrm{D}$ can result in hypercalcemia via two mechanisms. Firstly, by directly causing high intestinal calcium absorption and bone resorption that is in excess of the kidney's ability to handle the calcemic load. Secondly, by causing displacement of the active form of the vitamin from circulating DBP by high levels of $25(\mathrm{OH}) \mathrm{D}$, resulting in an elevation of free $1,25(\mathrm{OH})_{2} \mathrm{D}_{3}$ [88]. It appears that the daily intake of vitamin $\mathrm{D}$ necessary to achieve serum levels of $75-110 \mathrm{nmol} / \mathrm{L}$ is not associated with these risks. Excessive vitamin D intake (over 50,000 IU per day) is rarely associated with hypercalcemia [21]. Doses of $10,000 \mathrm{IU}$ of vitamin $\mathrm{D}_{3}$ per day for up to 5 months have not been found to cause toxicity [89].

\section{EVIDENCE FROM RECENT RANDOMIZED PLACEBO- CONTROLLED TRIALS OF VITAMIN D SUPPLEMENTATION IN PATIENTS WITH CHRONIC PAIN}

There are limited randomized double-blind placebo-controlled trials of vitamin D supplementation to determine the efficacy of 


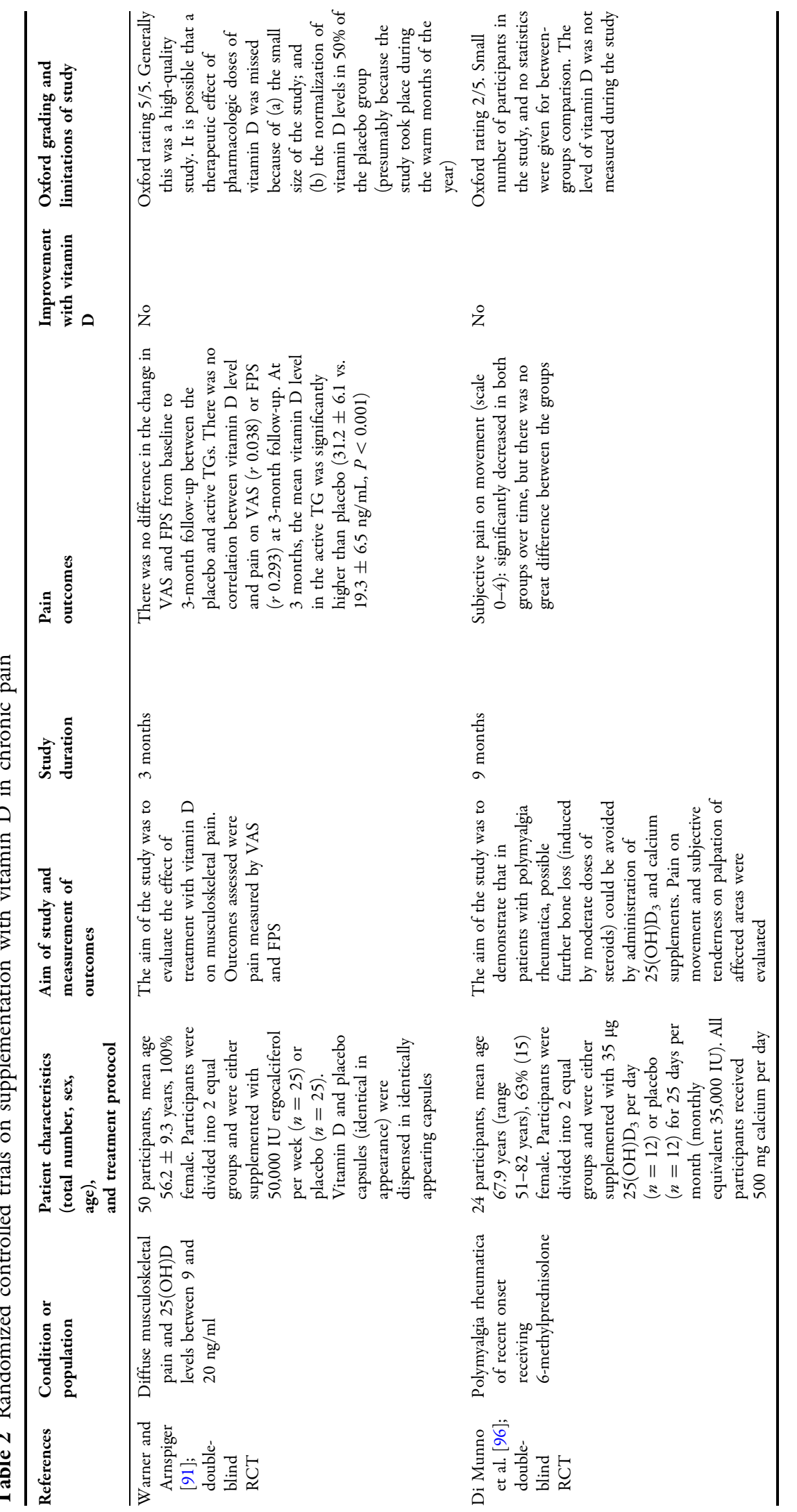




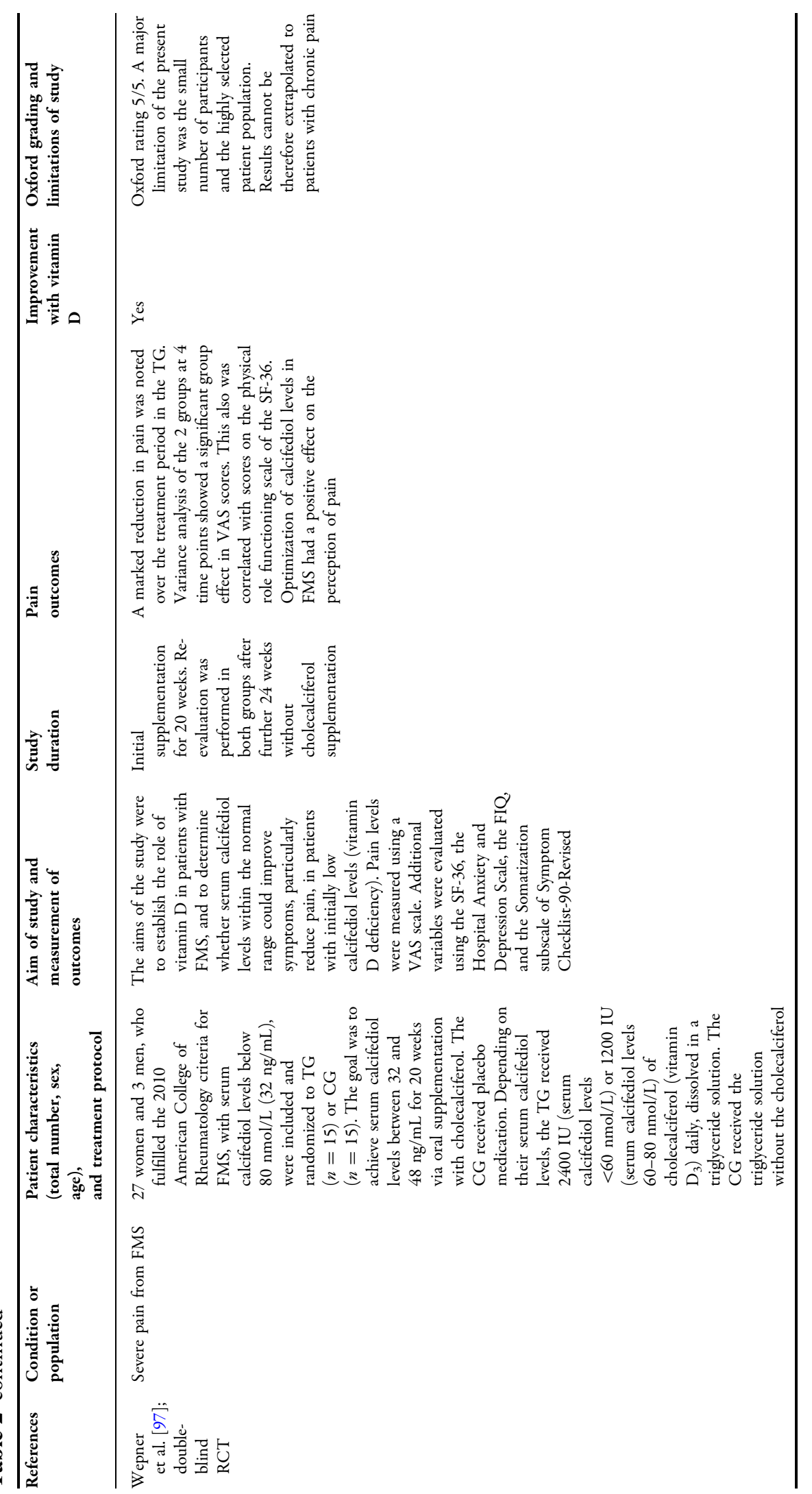




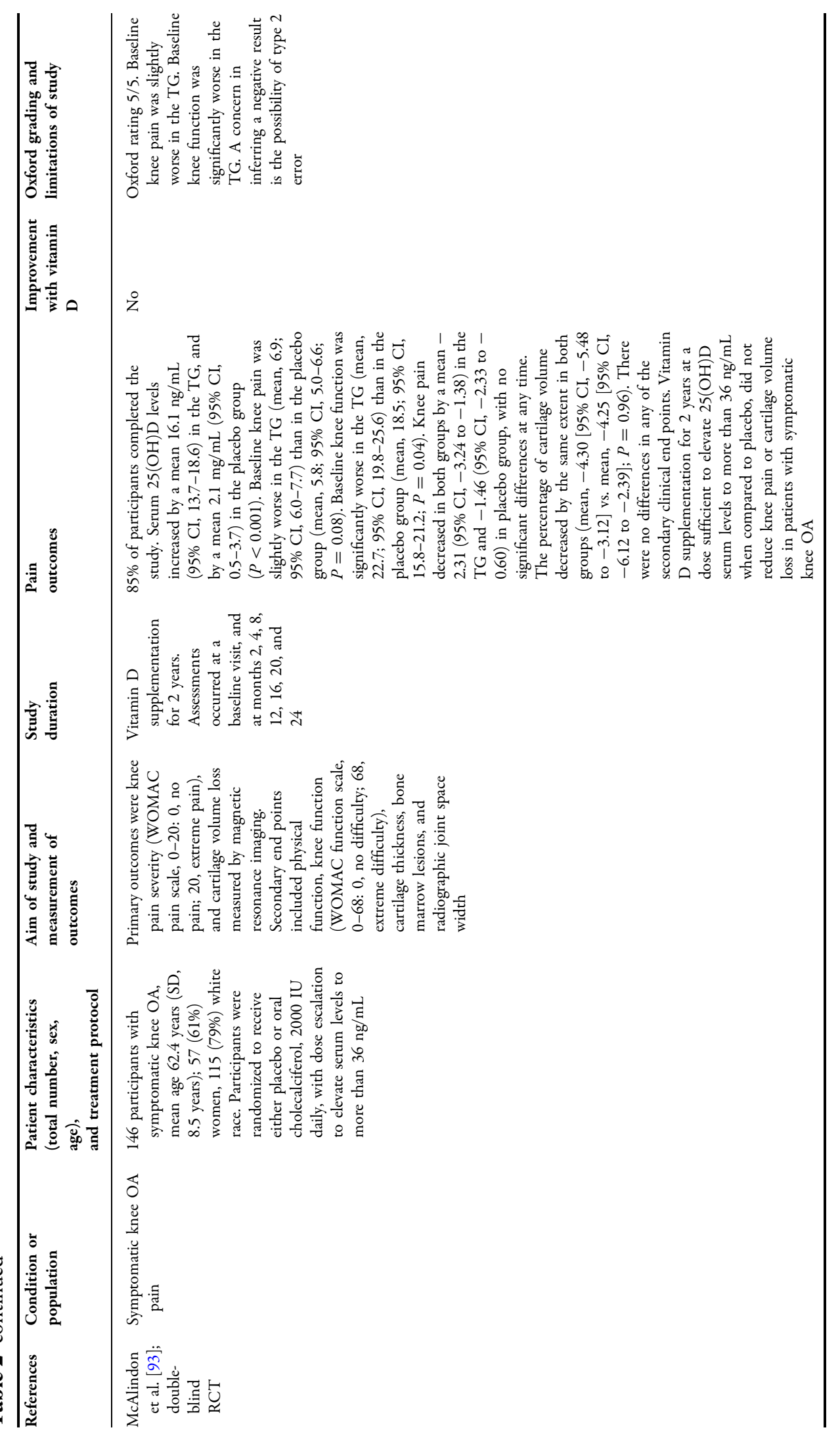




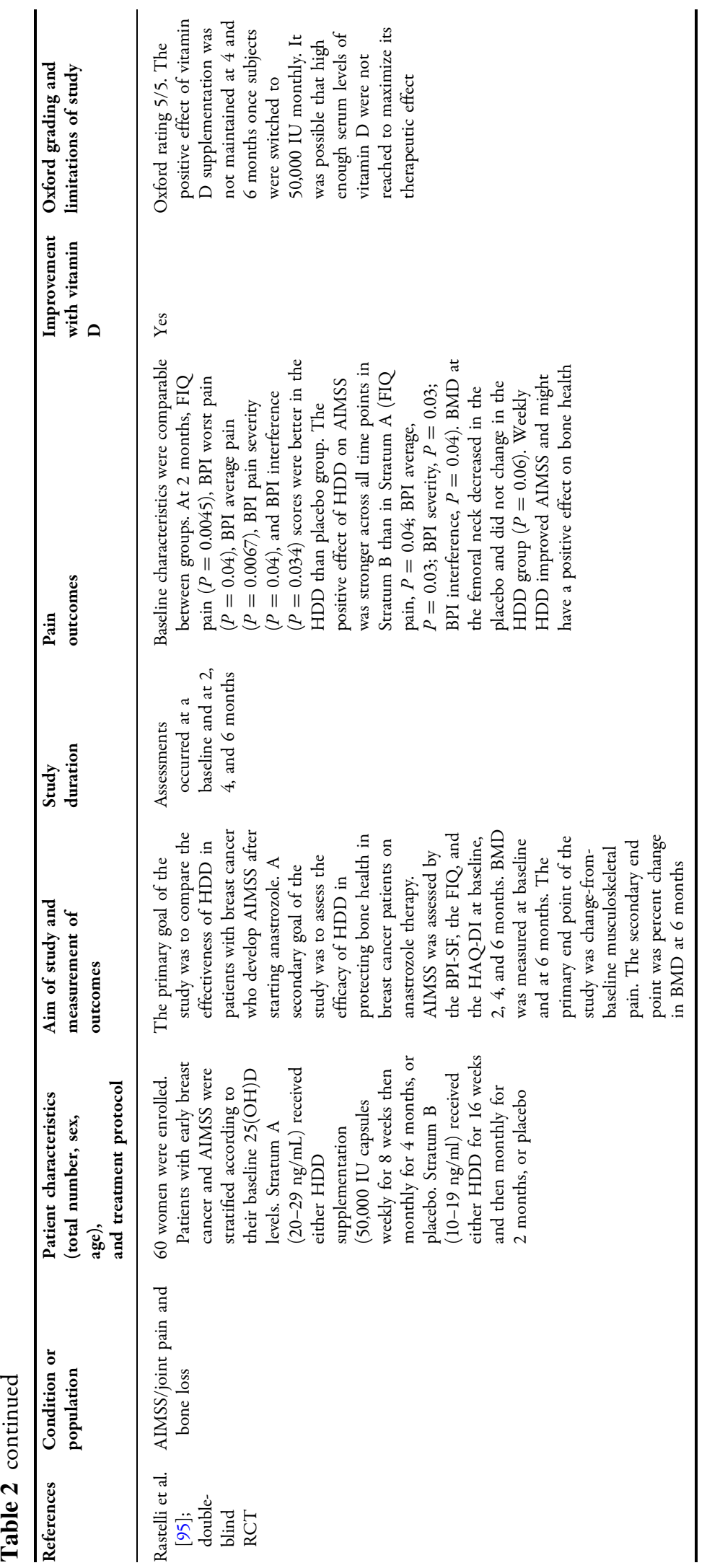




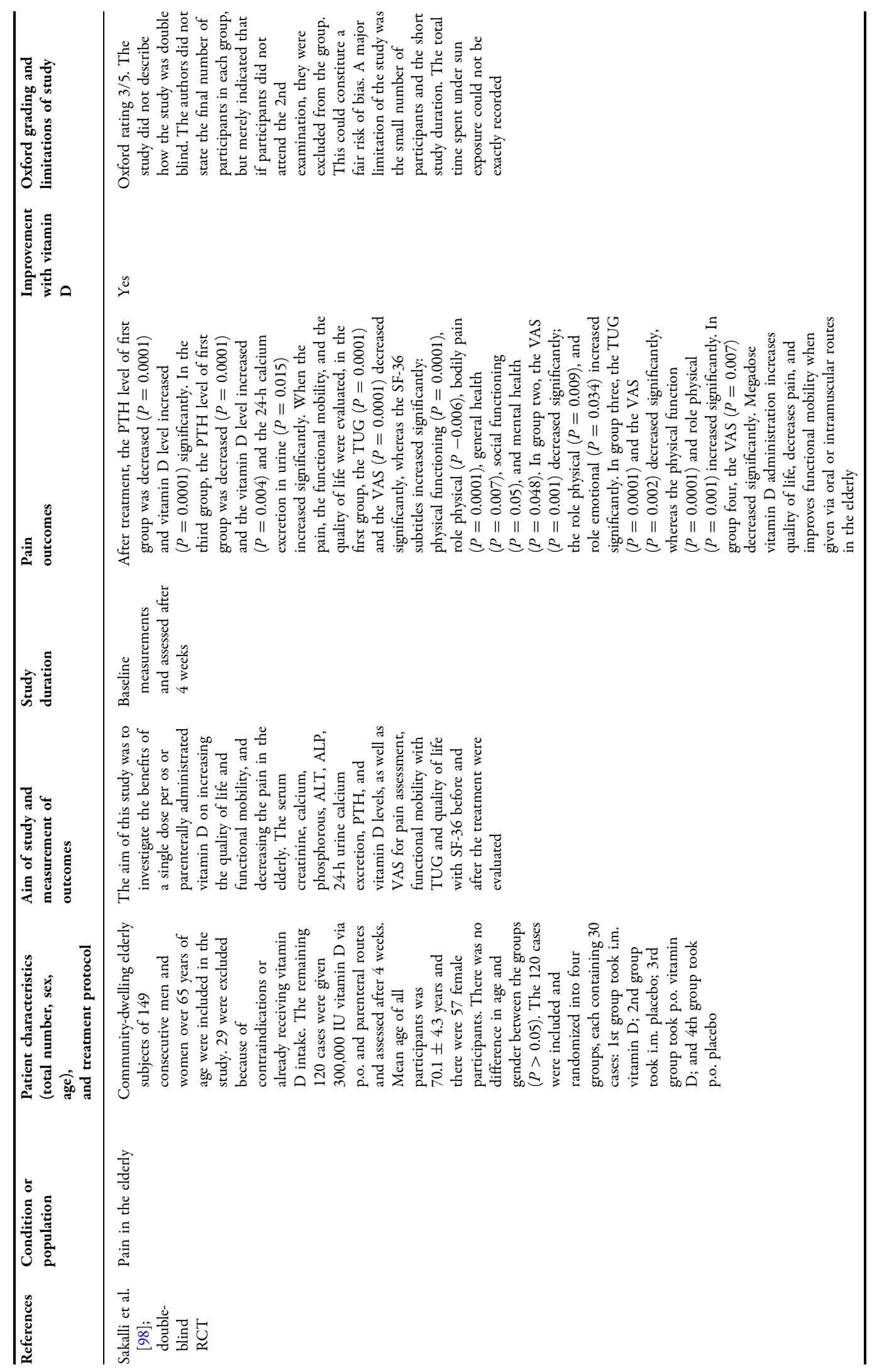




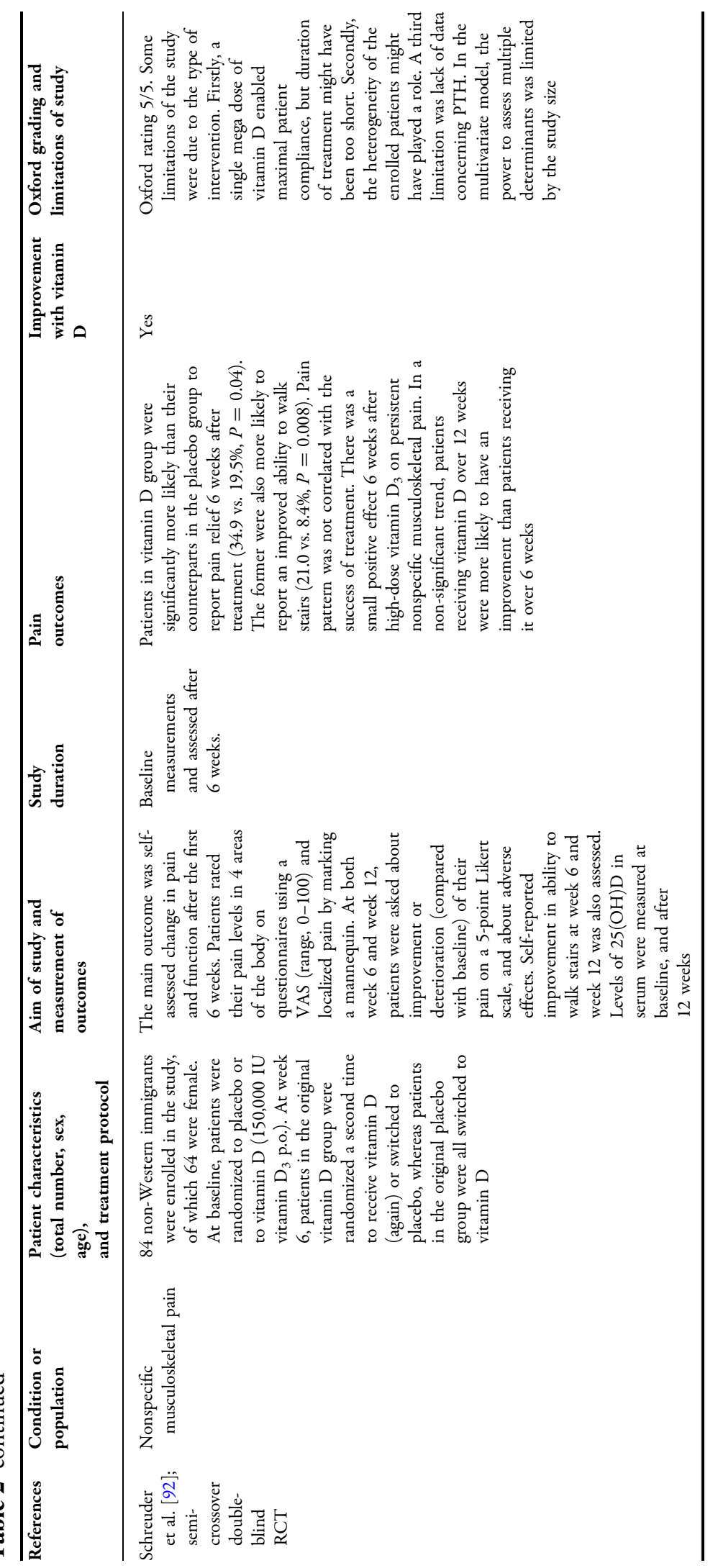




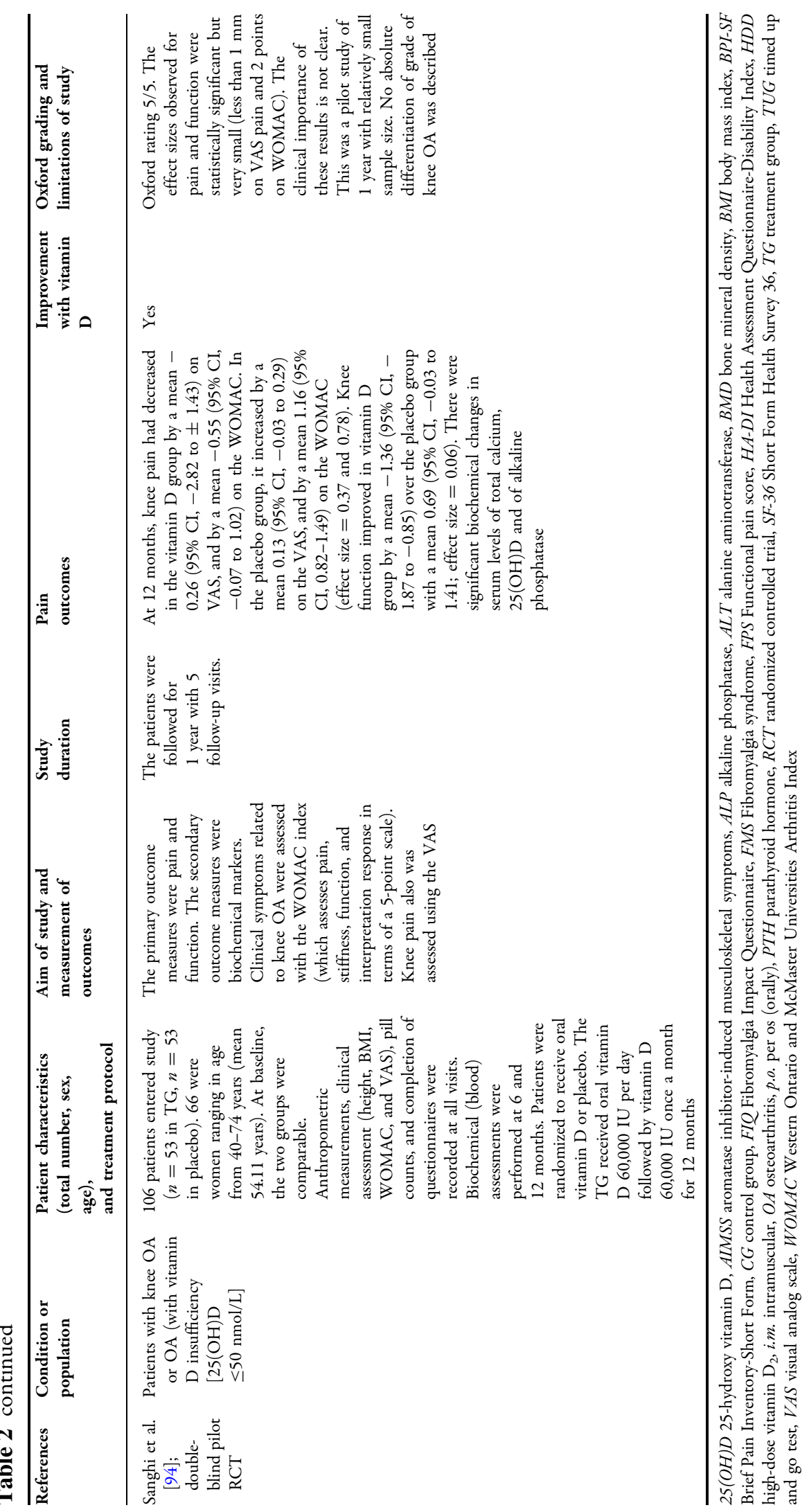


vitamin $D$ treatment in chronic pain conditions.

The authors searched MEDLINE (PubMed) using the search terms "vitamin D and pain". Limits in PubMed were set to "Randomized Controlled Trials" (RCTs) and "humans". Full publications in any language were included. The search was conducted on March 11, 2015. Two authors (E. E. S. and E. A. S.) independently reviewed all titles and abstracts identified by the search. Articles were selected for full-text review if inclusion criteria were met, or if either reviewer considered them potentially relevant. Clinical studies were included only if they reported on populations with chronic pain conditions and investigated pain outcomes after vitamin D supplementation. Data were collected regarding study design, chronic pain condition, population group, patient characteristics, mean or median 25(OH)D levels, treatment protocol (including types and doses of vitamin D preparations administered), concurrent other therapy, study duration, aim of the study, and pain outcomes. To be inclusive, chronic pain was defined in the broadest possible terms. An improvement of chronic pain with vitamin $\mathrm{D}$ treatment was defined as a statistically significant improvement compared to placebo. Pooled analysis was not undertaken due to the paucity and the heterogeneity of data. This article is based on previously conducted studies and does not involve any new studies of human or animal subjects performed by any of the authors.

The search identified 86 entries. Studies were included if they were double-blind RCTs of vitamin $\mathrm{D}$ supplementation compared to placebo in the treatment of chronic pain conditions.

Eight RCTs met these inclusion criteria. Seventy-eight studies were excluded based on the following criteria, namely: pain not measured as an outcome $(n=25)$; acute pain instead of chronic pain $(n=4)$; study was singly blinded or not specifically described as double blinded $(n=6)$; study design only $(n=1)$; not all participants had chronic pain $(n=1)$; there was no supplementation with vitamin D $(n=4)$; and the study did not control for vitamin $\mathrm{D}$ independent of other treatments $(n=37)$. Only one reason for exclusion was stated. However, some studies may have had more than one reason for exclusion (see Table $\mathrm{S} 1$ in the electronic supplementary material for details). The 8 data sets ranged in size from 24 to 146 participants. The total number of participants in the "pain" and "control" groups was 620 of which 396 were female. The majority of the studies were of high methodological quality (Oxford Quality Score 5/5) suggesting little likelihood of methodological bias [90].

There were five studies related to musculoskeletal pain [91-95], of which two were of diffuse or generalized musculoskeletal pain $[91,92]$. There were three studies of specific musculoskeletal pain, two involving osteoarthritis of the knees and one of aromatase inhibitor-induced musculoskeletal pain [93-95]. There was one study of each of the following: polymyalgia rheumatica [96]; fibromyalgia [97]; and generalized pain of the elderly [98]. Two studies [96, 98] had lower Oxford Quality Scores and were potentially prone to bias.

There were 5 studies, involving 400 participants, which showed a positive correlation between vitamin D supplementation and subjective pain rating. The four other studies (220 participants) showed no change in pain levels after supplementation. The supplementation regime varied widely and the vitamin $\mathrm{D}$ treatments involved monthly equivalent doses that varied 
from 35,000 to $300,000 \mathrm{IU}$. Duration of supplementation was from 1 to 24 months.

The results of this search are shown in Table 2 [91-98].

\section{DISCUSSION}

Evaluation of clinical studies regarding the use of vitamin $D$ for the treatment of chronic pain was previously undertaken in 2008 [6]. The authors searched MEDLINE (PubMed) using various search terms for vitamin $\mathrm{D}$ and pain prior to September 2008. Twenty-two relevant studies were identified that reported mean $25(\mathrm{OH}) \mathrm{D}$ levels and/or investigated the results of vitamin $\mathrm{D}$ treatment in patients with chronic pain conditions. Only five of these studies were randomized double-blind trials of vitamin $\mathrm{D}$ treatment. Vitamin D treatments involved monthly equivalent doses between 1200 and 400,000 IU. Fourteen studies were in musculoskeletal pain, five in chronic widespread pain or fibromyalgia, one in diabetic subjects with neuropathic pain, one addressing an unusual hyperaesthetic pain syndrome, and one in various conditions. Duration of treatment was from a few days to 12 months, although most studies lasted 2 months or more. Treatment studies involved 733 patients. Randomized double-blind trials involved 229 patients, of whom only 22 (10\%) were in a trial with a significant improvement in pain with vitamin $\mathrm{D}$, and then only on a pain mobility measure; 207 patients were involved in trials with no significant improvement in pain with vitamin $\mathrm{D}$. There was also no apparent correlation between significant improvement in pain with vitamin $\mathrm{D}$ and with a particular preparation, dose, or condition. There was no persuasive evidence of lower levels of $25(\mathrm{OH}) \mathrm{D}$ in those with chronic pain than in the control populations. There was a striking contrast in treatment effects between randomized, doubleblind trials that minimized bias and those with designs known to be subject to bias. In the former, only $10 \%$ of patients were in trials showing a benefit of vitamin D treatment; in the latter, 93\% were in trials showing a benefit of vitamin D treatment [6]. This study highlighted the need for further randomized double-blind placebo-controlled trials.

A Cochrane review of randomized doubleblind trials of vitamin D supplementation compared with placebo was published in 2010 [4]. The aim was to determine the efficacy of vitamin $\mathrm{D}$ in the treatment of chronic pain conditions. Only four studies (with a total of 294 participants) were included; eleven trials were excluded due to poor methodological design, or because not all participants received a clearly defined chronic pain diagnosis [4]. The studies included were similar in quality, used analogous chronic pain conditions with comparable outcome measures [91, 96, 99, 100]. Patients were supplemented with varying amounts and formulations of vitamin $\mathrm{D}$ for periods ranging from 16 weeks to 12 months. In summary, out of the four trials reviewed, the benefit of using vitamin $\mathrm{D}$ in chronic pain treatment was only shown in one trial. In the other three trials, there was no significant beneficial effect of vitamin $\mathrm{D}$ over placebo. Adverse effects of treatment were infrequent, and occurred at the same rates in vitamin $\mathrm{D}$ and placebo groups [96, 100].

Our study concurs with the results of the previous review on the subject published in 2009 and the Cochrane review published in 2010 , in that there is insufficient high-quality evidence for a definitive effect of vitamin $D$ in chronic pain. However, a trend appears in a positive direction indicating a beneficial effect of vitamin $\mathrm{D}$ over placebo in chronic pain. 
The number of randomized placebocontrolled double-blind studies is increasing which is encouraging. Six of the RCTs included in our study were published since 2011. Although the search strategy of this comprehensive review was thorough, it is possible that some randomized clinical trials might not have been located. A positive publication bias cannot be excluded as journals are reluctant to publish negative results. The overall picture generated by a review of this type could thus be a false positive.

\section{CONCLUSION}

Studies using visual analog scale (VAS) pain scores as the primary or solitary outcome measure have shown mixed results in chronic pain patients when evaluating the impact of vitamin D supplementation in this condition [82, 91, 101-103]. Significant improvements in assessment of sleep, mood, pain levels, wellbeing, and various aspects of quality of life with vitamin $\mathrm{D}$ supplementation have been shown [82, 104-107]. Whilst there is a growing body of both clinical and laboratory evidence pointing to a potential relationship between low levels of $25(\mathrm{OH}) \mathrm{D}$ and chronic pain, it is not possible to state conclusively that vitamin $\mathrm{D}$ deficiency is directly linked to the etiology or maintenance of chronic pain states. The scientific evidence for the use of vitamin $\mathrm{D}$ as a treatment option for chronic pain is limited at present due to low-quality designs, and due to the lack of RCTs.

A number of questions remain with regard to supplementation of vitamin D in patients with chronic pain. Vitamin D metabolism and action needs to be further elucidated including extrarenal activation and catabolism, distribution and mobilization from body pools, and its interaction with relevant genetic polymorphisms [8]. There remains some debate over the precise definition of vitamin $\mathrm{D}$ deficiency or insufficiency based on the serum levels of $25(\mathrm{OH}) \mathrm{D}$. The influence of age and body weight on the variability of the response of serum levels of $25(\mathrm{OH}) \mathrm{D}$ to intake needs to be clarified [8]. More focused research is necessary involving larger double-blind RCTs. These need to be stratified by baseline $25(\mathrm{OH}) \mathrm{D}$ levels, type of pain, and the use of adequate doses of vitamin $\mathrm{D}$ based on serum levels. More research is necessary to determine whether or not the effect of vitamin D supplementation is limited to patients who are vitamin D deficient. The optimal dose and length of time needed for supplementation need to be assessed as well.

\section{ACKNOWLEDGMENTS}

No funding contribution was received towards selection, extraction, or analysis of the data from any source, nor was any funding received for compilation of this article. Thanks to Dr. Jim Bartley for advice regarding preliminary work leading to this publication. All named authors meet the International Committee of Medical Journal Editors (ICMJE) criteria for authorship for this manuscript, take responsibility for the integrity of the work as a whole, and have given final approval for the version to be published.

Conflict of interest. Elspeth E. Shipton and Edward A. Shipton declare no conflict of interest regarding the publication of this paper.

Compliance with ethics guidelines. This article is based on previously conducted studies and does not involve any new studies of human or animal subjects performed by any of the authors. 
Open Access. This article is distributed under the terms of the Creative Commons Attribution Noncommercial License which permits any noncommercial use, distribution, and reproduction in any medium, provided the original author(s) and the source are credited.

\section{REFERENCES}

1. Hollis BW, Wagner CL. Clinical review: the role of the parent compound vitamin $\mathrm{D}$ with respect to metabolism and function: Why clinical dose intervals can affect clinical outcomes. J Clin Endocrin Metab. 2013;98(12):4619-28.

2. Mak JC, Klein LA, Finnegan T, Mason RS, Cameron ID. An initial loading-dose vitamin $\mathrm{D}$ versus placebo after hip fracture surgery: baseline characteristics of a randomized controlled trial (REVITAHIP). BMC Geriatr. 2014;14:101.

3. Atherton K, Berry DJ, Parsons T, Macfarlane GJ, Power C, Hypponen E. Vitamin D and chronic widespread pain in a white middle-aged British population: evidence from a cross-sectional population survey. Ann Rheum Dis. 2009;68(6):817-22.

4. Straube S, Derry S, Moore RA, McQuay HJ. Vitamin $\mathrm{D}$ for the treatment of chronic painful conditions in adults. Cochrane Database Syst Rev. 2010(1):CD007771.

5. McAlindon TE, Felson DT, Zhang Y, Hannan MT, Aliabadi P, Weissman B, et al. Relation of dietary intake and serum levels of vitamin $\mathrm{D}$ to progression of osteoarthritis of the knee among participants in the Framingham Study. Ann Intern Med. 1996;125(5):353-9.

6. Straube S, Andrew Moore R, Derry S, McQuay HJ. Vitamin D and chronic pain. Pain. 2009;141(1-2):10-3.

7. Deeb KK, Trump DL, Johnson CS. Vitamin D signalling pathways in cancer: potential for anticancer therapeutics. Nat Rev Cancer. 2007;7(9):684-700.

8. Brannon PM. Key questions in vitamin D research. Scand J Clin Lab Invest Suppl. 2012;243:154-62.

9. Adams JS, Hewison M. Update in vitamin D. J Clin Endocrin Metab. 2010;95(2):471-8.
10. Zerwekh JE. Blood biomarkers of vitamin D status. Am J Clin Nutr. 2008;87(4):1087S-91S.

11. International Association for the Study of Pain Subcommittee. Classification of chronic pain. Descriptions of chronic pain syndromes and definitions of pain terms. Pain Suppl. 1986;3:S1-226.

12. Seifert F, Maihofner C. Functional and structural imaging of pain-induced neuroplasticity. Curr Opin Anaesthesiol. 2011;24(5):515-23.

13. Latremoliere A, Woolf CJ. Central sensitization: a generator of pain hypersensitivity by central neural plasticity. J Pain. 2009;10(9):895-926.

14. Flor H, Elbert T, Knecht S, Wienbruch C, Pantev C, Birbaumer $\mathrm{N}$, et al. Phantom-limb pain as a perceptual correlate of cortical reorganization following arm amputation. Nature. 1995;375(6531):482-4.

15. Basbaum A, Bushnel 1C, Devor M. Pain: basic mechanisms. In: Pain 2005-an updated review: refresher course syllabus. Seattle: IASP Press; 2005.

16. Woolf CJ, Ma Q. Nociceptors-noxious stimulus detectors. Neuron. 2007;55(3):353-64.

17. Stein C. Opioids, sensory systems and chronic pain. Eur J Pharmacol. 2013;716(1-3):179-87.

18. Moseley GL, Vlaeyen JW. Beyond nociception: the imprecision hypothesis of chronic pain. Pain. $2015 ; 156(1): 35-8$.

19. Moalem G, Tracey DJ. Immune and inflammatory mechanisms in neuropathic pain. Brain Res Rev. 2006;51(2):240-64.

20. Siddall PJ, Cousins MJ. Persistent pain as a disease entity: implications for clinical management. Anesth Analg. 2004;99(2):510-20.

21. Holick MF. Vitamin D deficiency. N Engl J Med. 2007;357(3):266-81.

22. Plotnikoff GA, Quigley JM. Prevalence of severe hypovitaminosis D in patients with persistent, nonspecific musculoskeletal pain. Mayo Clin Proc. 2003;78(12):1463-70.

23. Cutolo M, Paolino S, Sulli A, Smith V, Pizzorni C, Seriolo B. Vitamin D, steroid hormones, and autoimmunity. Ann N Y Acad Sci. 2014;1317:39-46.

24. Jesus CA, Feder D, Peres MF. The role of vitamin D in pathophysiology and treatment of fibromyalgia. Curr Pain Headache Rep. 2013;17(8):355. 
25. Liao RX, Yu M, Jiang Y, Xia W. Management of osteoporosis with calcitriol in elderly Chinese patients: a systematic review. Clin Interv Aging. 2014;9:515-26.

26. Gloth FM 3rd, Lindsay JM, Zelesnick LB, Greenough WB 3rd. Can vitamin D deficiency produce an unusual pain syndrome? Arch Intern Med. 1991;151(8):1662-4.

27. Simpson RU, Thomas GA, Arnold AJ. Identification of 1,25-dihydroxyvitamin D3 receptors and activities in muscle. J Biol Chem. 1985;260(15):8882-91.

28. Bischoff HA, Stahelin HB, Dick W, Akos R, Knecht M, Salis C, et al. Effects of vitamin D and calcium supplementation on falls: a randomized controlled trial. J Bone Miner Res. 2003;18(2):343-51.

29. Hayes M, Yaster M, Haythornthwaite JA, Riekert KA, McMillan KN, White E, et al. Pain is a common problem affecting clinical outcomes in adults with cystic fibrosis. Chest. 2011;140(6):1598-603.

30. West NE, Lechtzin N, Merlo CA, Turowski JB, Davis ME, Ramsay MZ, et al. Appropriate goal level for 25-hydroxyvitamin $\mathrm{D}$ in cystic fibrosis. Chest. 2011;140(2):469-74.

31. von Kanel R, Muller-Hartmannsgruber V, Kokinogenis G, Egloff N. Vitamin D and central hypersensitivity in patients with chronic pain. Pain Med. 2014;15(9):1609-18.

32. Bartley J. Could glial activation be a factor in migraine? Med Hypotheses. 2009;72(3):255-7.

33. Woolf CJ. Central sensitization: implications for the diagnosis and treatment of pain. Pain. 2011;152(3 Suppl):S2-15.

34. Zakon HH. The effects of steroid hormones on electrical activity of excitable cells. Trends Neurosci. 1998;21(5):202-7.

35. Wu FS, Gibbs TT, Farb DH. Pregnenolone sulfate: a positive allosteric modulator at the $N$-methyl-Daspartate receptor. Mol Pharmacol. 1991;40(3):333-6.

36. Mensah-Nyagan AG, Meyer L, Schaeffer V, Kibaly C, Patte-Mensah C. Evidence for a key role of steroids in the modulation of pain. Psychoneuroendocrinology. 2009;34(Suppl 1):S169-77.

37. Brown J, Bianco JI, McGrath JJ, Eyles DW. 1,25dihydroxyvitamin D3 induces nerve growth factor, promotes neurite outgrowth and inhibits mitosis in embryonic rat hippocampal neurons. Neurosci Lett. 2003;343(2):139-43.
38. Garcion E, Wion-Barbot N, Montero-Menei CN, Berger F, Wion D. New clues about vitamin D functions in the nervous system. Trends Endocrinol Metab. 2002;13(3):100-5.

39. Leung L, Cahill CM. TNF-alpha and neuropathic pain. J Neuroinflammation. 2010;7:27.

40. Marchand F, Perretti M, McMahon SB. Role of the immune system in chronic pain. Nat Rev Neurosci. 2005;6(7):521-32.

41. Prakash S, Mehta NC, Dabhi AS, Lakhani O, Khilari $\mathrm{M}$, Shah ND. The prevalence of headache may be related with the latitude: a possible role of Vitamin D insufficiency? J Headache Pain. 2010;11(4):301-7.

42. Neveu I, Naveilhan P, Jehan F, Baudet C, Wion D, De Luca $\mathrm{HF}$, et al. 1,25-dihydroxyvitamin D3 regulates the synthesis of nerve growth factor in primary cultures of glial cells. Brain Res Mol Brain Res. 1994;24(1-4):70-6.

43. Riaz S, Malcangio M, Miller M, Tomlinson DR. A vitamin $\mathrm{D}(3)$ derivative (CB1093) induces nerve growth factor and prevents neurotrophic deficits in streptozotocin-diabetic rats. Diabetologia. 1999;42(11):1308-13.

44. Sanchez B, Relova JL, Gallego R, Ben-Batalla I, PerezFernandez R. 1,25-Dihydroxyvitamin D3 administration to 6-hydroxydopamine-lesioned rats increases glial cell line-derived neurotrophic factor and partially restores tyrosine hydroxylase expression in substantia nigra and striatum. J Neurosci Res. 2009;87(3):723-32.

45. Burgess G, Williams D. The discovery and development of analgesics: new mechanisms, new modalities. J Clin Invest. 2010;120(11):3753-9.

46. Woolf CJ. Phenotypic modification of primary sensory neurons: the role of nerve growth factor in the production of persistent pain. Philos Trans $\mathrm{R}$ Soc Lond B Biol Sci. 1996;351(1338):441-8.

47. McKelvey L, Shorten GD, O'Keeffe GW. Nerve growth factor-mediated regulation of pain signalling and proposed new intervention strategies in clinical pain management. J Neurochem. 2013;124(3):276-89.

48. Osunkwo I, Ziegler TR, Alvarez J, McCracken C, Cherry K, Osunkwo CE, et al. High dose vitamin D therapy for chronic pain in children and adolescents with sickle cell disease: results of a randomized double blind pilot study. $\mathrm{Br} \mathrm{J}$ Haematol. 2012;159(2):211-5.

49. Holick MF, Binkley NC, Bischoff-Ferrari HA, Gordon CM, Hanley DA, Heaney RP, et al. Evaluation, treatment, and prevention of vitamin D 
deficiency: an Endocrine Society clinical practice guideline. J Clin Endocrin Metab. 2011;96(7):1911-30.

50. Sinha A, Cheetham TD, Pearce SH. Prevention and treatment of vitamin D deficiency. Calcif Tissue Int. 2013;92(2):207-15.

51. Glerup H, Mikkelsen K, Poulsen L, Hass E, Overbeck $\mathrm{S}$, Thomsen J, et al. Commonly recommended daily intake of vitamin D is not sufficient if sunlight exposure is limited. J Intern Med. 2000;247(2):260-8.

52. Zadshir A, Tareen N, Pan D, Norris K, Martins D. The prevalence of hypovitaminosis $\mathrm{D}$ among US adults: data from the NHANES III. Ethn Dis. 2005;15(4 Suppl 5):S5-97-101.

53. Allain TJ, Dhesi J. Hypovitaminosis D in older adults. Gerontol. 2003;49(5):273-8.

54. van Schoor NM, Lips P. Worldwide vitamin D status. Best Pract Res Clin Endocrinol Metab. 2011;25(4):671-80.

55. Wagner CL, Greer FR. Prevention of rickets and vitamin D deficiency in infants, children, and adolescents. Pediatrics. 2008;122(5):1142-52.

56. Mascitelli L, Goldstein MR, Grant WB. Hypovitaminosis D and pain in cystic fibrosis. Pain Med. 2012;13(5):735-6.

57. Konradsen S, Ag H, Lindberg F, Hexeberg S, Jorde R. Serum 1,25-dihydroxy vitamin $\mathrm{D}$ is inversely associated with body mass index. Eur J Nutr. 2008;47(2):87-91.

58. McGill AT, Stewart JM, Lithander FE, Strik CM, Poppitt SD. Relationships of low serum vitamin D3 with anthropometry and markers of the metabolic syndrome and diabetes in overweight and obesity. Nutr J. 2008;7:4.

59. Parikh SJ, Edelman M, Uwaifo GI, Freedman RJ, Semega-Janneh $M$, Reynolds $J$, et al. The relationship between obesity and serum 1,25dihydroxy vitamin D concentrations in healthy adults. J Clin Endocrin Metab. 2004;89(3):1196-9.

60. Vilarrasa N, Maravall J, Estepa A, Sanchez R, Masdevall C, Navarro MA, et al. Low 25-hydroxyvitamin D concentrations in obese women: their clinical significance and relationship with anthropometric and body composition variables. J Endocrinol Invest. 2007;30(8):653-8.

61. Young KA, Engelman CD, Langefeld CD, Hairston KG, Haffner SM, Bryer-Ash M, et al. Association of plasma vitamin D levels with adiposity in Hispanic and African Americans. J Clin Endocrin Metab. 2009;94(9):3306-13.

62. Brannon PM, Yetley EA, Bailey RL, Picciano MF. Summary of roundtable discussion on vitamin $\mathrm{D}$ research needs. Am J Clin Nutr. 2008;88(2):587S92S.

63. Ritter CS, Brown AJ. Direct suppression of PTH gene expression by the vitamin $\mathrm{D}$ prohormones doxercalciferol and calcidiol requires the vitamin D receptor. J Mol Endocrinol. 2011;46(2):63-6.

64. Shinchuk LM, Holick MF. Vitamin D and rehabilitation: improving functional outcomes. Nutr Clin Pract. 2007;22(3):297-304.

65. Thacher TD, Clarke BL. Vitamin D insufficiency. Mayo Clin Proc. 2011;86(1):50-60.

66. Souberbielle JC, Courbebaisse M, Cormier C, Pierrot-Deseilligny C, Viard JP, Jean G, et al. When should we measure vitamin $\mathrm{D}$ concentration in clinical practice? Scand J Clin Lab Invest Suppl. 2012;243:129-35.

67. Bischoff-Ferrari HA, Giovannucci E, Willett WC, Dietrich T, Dawson-Hughes B. Estimation of optimal serum concentrations of 25-hydroxyvitamin D for multiple health outcomes. Am J Clin Nutr. 2006;84(1):18-28.

68. Sanders KM, Stuart AL, Williamson EJ, Simpson JA, Kotowicz MA, Young D, et al. Annual high-dose oral vitamin $\mathrm{D}$ and falls and fractures in older women: a randomized controlled trial. JAMA. 2010;303(18):1815-22.

69. Heaney RP, Armas LA, Shary JR, Bell NH, Binkley N, Hollis BW. 25-Hydroxylation of vitamin D3: relation to circulating vitamin D3 under various input conditions. Am J Clin Nutr. 2008;87(6):1738-42.

70. Hollis BW. Short-term and long-term consequences and concerns regarding valid assessment of vitamin D deficiency: comparison of recent food supplementation and clinical guidance reports. Curr Opin Clin Nutr Metab Care. 2011;14(6):598-604.

71. Rapuri PB, Gallagher JC, Haynatzki G. Effect of vitamins D2 and D3 supplement use on serum $25 \mathrm{OHD}$ concentration in elderly women in summer and winter. Calcif Tissue Int. 2004;74(2):150-6.

72. Binkley N, Gemar D, Engelke J, Gangnon R, Ramamurthy R, Krueger D, et al. Evaluation of ergocalciferol or cholecalciferol dosing, 1,600 IU daily or 50,000 IU monthly in older adults. J Clin Endocrin Metab. 2011;96(4):981-8. 
73. Marshall DT, Savage SJ, Garrett-Mayer E, Keane TE, Hollis BW, Horst RL, et al. Vitamin D3 supplementation at 4000 international units per day for one year results in a decrease of positive cores at repeat biopsy in subjects with low-risk prostate cancer under active surveillance. J Clin Endocrin Metab. 2012;97(7):2315-24.

74. Khazai NB, Judd SE, Jeng L, Wolfenden LL, Stecenko A, Ziegler TR, et al. Treatment and prevention of vitamin D insufficiency in cystic fibrosis patients: comparative 25 efficacy of ergocalciferol, cholecalciferol, and UV light. J Clin Endocrin Metab. 2009;94(6):2037-43.

75. Lips P, Binkley N, Pfeifer M, Recker R, Samanta S, Cohn DA, et al. Once-weekly dose of $8400 \mathrm{IU}$ vitamin $\mathrm{D}(3)$ compared with placebo: effects on neuromuscular function and tolerability in older adults with vitamin D insufficiency. J Clin Endocrin Metab. 2010;91(4):985-91.

76. Cipriani C, Romagnoli E, Scillitani A, Chiodini I, Clerico R, Carnevale V, et al. Effect of a single oral dose of $600,000 \mathrm{IU}$ of cholecalciferol on serum calciotropic hormones in young subjects with vitamin $D$ deficiency: a prospective intervention study. J Clin Endocrin Metab. 2010;95(10):4771-7.

77. Malhotra N, Mithal A, Gupta S, Shukla M, Godbole M. Effect of vitamin D supplementation on bone health parameters of healthy young Indian women. Arch Osteoporos. 2009;4(1-2):47-53.

78. Trivedi DP, Doll R, Khaw KT. Effect of four monthly oral vitamin D3 (cholecalciferol) supplementation on fractures and mortality in men and women living in the community: randomised double blind controlled trial. BMJ. 2003;326(7387):469.

79. Vieth R, Chan PC, MacFarlane GD. Efficacy and safety of vitamin D3 intake exceeding the lowest observed adverse effect level. Am J Clin Nutr. 2001;73(2):288-94.

80. Holick MF, Chen TC. Vitamin D deficiency: a worldwide problem with health consequences. Am J Clin Nutr. 2008;87(4):1080S-6S.

81. Bergman $P$, Lindh AU, Bjorkhem-Bergman L, Lindh JD. Vitamin D and respiratory tract infections: a systematic review and meta-analysis of randomized controlled trials. PLoS One. 2013;8(6):e65835.

82. Huang W, Shah S, Long Q, Crankshaw AK, Tangpricha V. Improvement of pain, sleep, and quality of life in chronic pain patients with vitamin D supplementation. Clin J Pain. 2013;29(4):341-7.

83. Holick MF, Biancuzzo RM, Chen TC, Klein EK, Young A, Bibuld D, et al. Vitamin D2 is as effective as vitamin D3 in maintaining circulating concentrations of 25-hydroxyvitamin D. J Clin Endocrin Metab. 2008;93(3):677-81.

84. Heaney RP, Davies KM, Chen TC, Holick MF, Barger-Lux MJ. Human serum 25-hydroxycholecalciferol response to extended oral dosing with cholecalciferol. Am J Clin Nutr. 2003;77(1):204-10.

85. Mocanu V, Stitt PA, Costan AR, Voroniuc O, Zbranca E, Luca $\mathrm{V}$, et al. Long-term effects of giving nursing home residents bread fortified with 125 microg (5000 IU) vitamin $\mathrm{D}(3)$ per daily serving. Am J Clin Nutr. 2009;89(4):1132-7.

86. Patel R, Collins D, Bullock S, Swaminathan R, Blake GM, Fogelman I. The effect of season and vitamin D supplementation on bone mineral density in healthy women: a double-masked crossover study. Osteoporos Int. 2001;12(4):319-25.

87. Smith SM, Gardner KK, Locke J, Zwart SR. Vitamin D supplementation during Antarctic winter. Am J Clin Nutr. 2009;89(4):1092-8.

88. Heaney RP. Vitamin D: criteria for safety and efficacy. Nutrition Rev. 2008;66(10 Suppl 2):S178-81.

89. Vieth R. Why the optimal requirement for Vitamin D3 is probably much higher than what is officially recommended for adults. J Steroid Biochem Mol Biol. 2004;89-90(1-5):575-9.

90. Jadad AR, Moore RA, Carroll D, Jenkinson C, Reynolds DJ, Gavaghan DJ, et al. Assessing the quality of reports of randomized clinical trials: is blinding necessary? Control Clin Trials. 1996;17(1):1-12.

91. Warner AE, Arnspiger SA. Diffuse musculoskeletal pain is not associated with low vitamin D levels or improved by treatment with vitamin D. J Clin Rheumatol. 2008;14(1):12-6.

92. Schreuder F, Bernsen RM, van der Wouden JC. Vitamin D supplementation for nonspecific musculoskeletal pain in non-Western immigrants: a randomized controlled trial. Ann Fam Med. $2012 ; 10(6): 547-55$.

93. McAlindon T, LaValley $M$, Schneider E, Nuite $M$, Lee JY, Price LL, et al. Effect of vitamin D supplementation on progression of knee pain and cartilage volume loss in patients with symptomatic osteoarthritis: a randomized controlled trial. JAMA. 2013;309(2):155-62.

94. Sanghi D, Mishra A, Sharma AC, Singh A, Natu SM, Agarwal $S$, et al. Does vitamin $D$ improve osteoarthritis of the knee: a randomized controlled pilot trial. Clin Orthop Relat Res. 2013;471(11):3556-62. 
95. Rastelli AL, Taylor ME, Gao F, Armamento-Villareal R, Jamalabadi-Majidi S, Napoli N, et al. Vitamin D and aromatase inhibitor-induced musculoskeletal symptoms (AIMSS): a phase II, double-blind, placebo-controlled, randomized trial. Breast Cancer Res Treat. 2011;129(1):107-16.

96. Di Munno O, Beghe F, Favini P, Di Giuseppe P, Pontrandolfo A, Occhipinti G, et al. Prevention of glucocorticoid-induced osteopenia: effect of oral 25-hydroxyvitamin D and calcium. Clin Rheumatol. 1989;8(2):202-7.

97. Wepner F, Scheuer R, Schuetz-Wieser B, Machacek P, Pieler-Bruha E, Cross HS, et al. Effects of vitamin $\mathrm{D}$ on patients with fibromyalgia syndrome: a randomized placebo-controlled trial. Pain. $2014 ; 155(2): 261-8$

98. Sakalli H, Arslan D, Yucel AE. The effect of oral and parenteral vitamin $\mathrm{D}$ supplementation in the elderly: a prospective, double-blinded, randomized, placebo controlled study. Rheumatol Int. 2012;32(8):2279-83.

99. Brohult J, Jonson B. Effects of large doses of calciferol on patients with rheumatoid arthritis. A double-blind clinical trial. Scand J Rheumatol. 1973;2(4):173-6.

100. Yamauchi Y, Tsunematsu T, Konda S, Hoshino T, Itokawa Y, Hoshizaki H. A double blind trial of alfacalcidol on patients with rheumatoid arthritis (RA). Rheumatism. 1989;29(1):11-24.

101. Lee P, Chen R. Vitamin D as an analgesic for patients with type 2 diabetes and neuropathic pain. Arch Intern Med. 2008;168(7):771-2.
102. Iwamoto J, Takeda T, Ichimura S, Matsu K, Uzawa M. Effects of cyclical etidronate with alfacalcidol on lumbar bone mineral density, bone resorption, and back pain in postmenopausal women with osteoporosis. J Orthop Sci. 2003;8(4):532-7.

103. de Torrente de la Jara G, Pecoud A, Favrat B. Musculoskeletal pain in female asylum seekers and hypovitaminosis D3. BMJ. 2004;329(7458):156-7.

104. Spedding S. Vitamin D and depression: a systematic review and meta-analysis comparing studies with and without biological flaws. Nutrients. 2014;6(4):1501-18.

105. Hogberg G, Gustafsson SA, Hallstrom T, Gustafsson T, Klawitter B, Petersson M. Depressed adolescents in a case-series were low in vitamin $\mathrm{D}$ and depression was ameliorated by vitamin D supplementation. Acta Paediatr. 2012;101(7):779-83.

106. Basaran S, Guzel R, Coskun-Benlidayi I, Guler-Uysal F. Vitamin D status: effects on quality of life in osteoporosis among Turkish women. Qual Life Res. 2007;16(9):1491-9.

107. Vieth R, Kimball S, Hu A, Walfish PG. Randomized comparison of the effects of the vitamin D3 adequate intake versus $100 \mathrm{mcg}$ (4000 IU) per day on biochemical responses and the wellbeing of patients. Nutr J. 2004;3:8. 